\title{
Features of the Sediment Runoff Regime Downstream the lle River
}

\author{
Kassym Duskayev ${ }^{1}$, Akhan Myrzakhmetov ${ }^{1,2^{*}}$, Zhanar Zhanabayeva', Igor Klein ${ }^{3}$ \\ 1 Department of meteorology and hydrology, Al-Farabi Kazakh National University, Almaty, Kazakhstan \\ 2 Water resources Laboratory, Institute of Geography, Almaty, Kazakhstan \\ ${ }^{3}$ DLR, Germany \\ *Corresponding author's e-mail: ahan_myrzahmetov@mail.ru
}

\begin{abstract}
This paper is devoted to study on the sediment runoff of the Ile River downstream. The article analyses the Kapshagai reservoir impact on the regime and characteristics of the sediment runoff in the Ile River downstream before and after construction of the reservoir in 1970. Along with the calculation of characteristics of sediment runoff, an assessment of the amount of the suspended sediment, which is in the bowl of the reservoir, was shown. Furthermore, the impact reservoir on the granulometric composition of the suspended and bed sediment of Ile River was calculated.
\end{abstract}

Keywords: sediment transport, sediment runoff characteristics, suspended load, bed load, granulometric composition

\section{INTRODUCTION}

The Ile River is one of the largest transboundary rivers located in the South-East of Kazakhstan (Fig. 1). Currently, the water resources of the Ile River play an important role for both the BalkashAlakol basin and for the economy of the Republic of Kazakhstan as well as for China. Realization of the plans for sustainable use and preservation of the water resources of the Ile River is possible only on the basis of reliable data of all hydrological characteristics. Above all, the quality of water, as well as the characteristics of liquid and solid river runoff, refer to the main hydrological characteristics of the Ile river in its lower reaches [1-6].

For perennial control of Ile River runoff, the Kapshagai reservoir with area surface of $1.847 \mathrm{~km}^{2}$ and a length of $180 \mathrm{~km}$ was build, its project capacity was equal to $28.1 \mathrm{~km}^{3}$. The main goal of building the Kapshagai reservoir on the Ile River was the development of irrigated lands in the river's downstream with an area of 430 thousand hectares and to provide the region with necessary electricity [7].

The filling of the Kapshagai reservoir was started in 1969, and by 1985 the filled water volume was $13.99 \mathrm{~km}^{3}$, which is just $50 \%$ of the planned project volume.

Since the moment when the Kapshagai reservoir started operation, a number of negative consequences started to appear in the river basin, especially in the downstream. For instance, high daily deviations of flow in the tail-water of the Kapshagai reservoir led to a disturbance of the natural hydroecological regime. As a result of water evacuation to tail-water, waves, which reach the boundaries of the modern delta of the Ile River and increase erosion of the river in the tail-water of reservoir, are formed. According to the measurements of the Kazakh Scientific-Research institute of Ecology and Climate, another negative factor of creating the reservoir is the irrecoverable loss of the water runoff - from the water area of the reservoir. According to the experts' assessment, this value reaches $1.5-2 \mathrm{~km}^{3}$ per year [8].

The delta of the Ile River occupies about $20 \mathrm{~km}^{2}$ of Pre-Balkash Lake region are. Out of them, $8 \mathrm{~km}^{2}$ is the area of modern delta, the Akdala-Bakanas river mouth is located in the remaining part (compare Fig. 1). In this figure, a view of the Ile River's modern delta is similar to an 
isosceles triangle with the base of $210 \mathrm{~km}$ (along the coastal line of Balkash Lake) and the length in a straight line of $125 \mathrm{~km}$ (Fig. 2).

The Ile River's delta begins $140 \mathrm{~km}$ from Lake Balkash, near the village of Akkol. At this place, the river channel branches into three inflows: the north-east - arm Zhideli, central - Ile, south - arm Topar. The eastern boundary of the delta is sand Saryesik constituting an ancient delta of river and the southern boundary of the sand Taukum. The significant volumes of sediment transport, which are formed as a result of that reduce the conveyance capacity of the river arms while moving to the river delta and sharply decrease the transportation capacity of the watercourses of the delta and the channel of the river itself $[9,10]$.

\section{MATERIALS}

The main part of the sediment load transported by inflows of the Ile River's delta (66-99\% of annual runoff) passes in the spring and summer

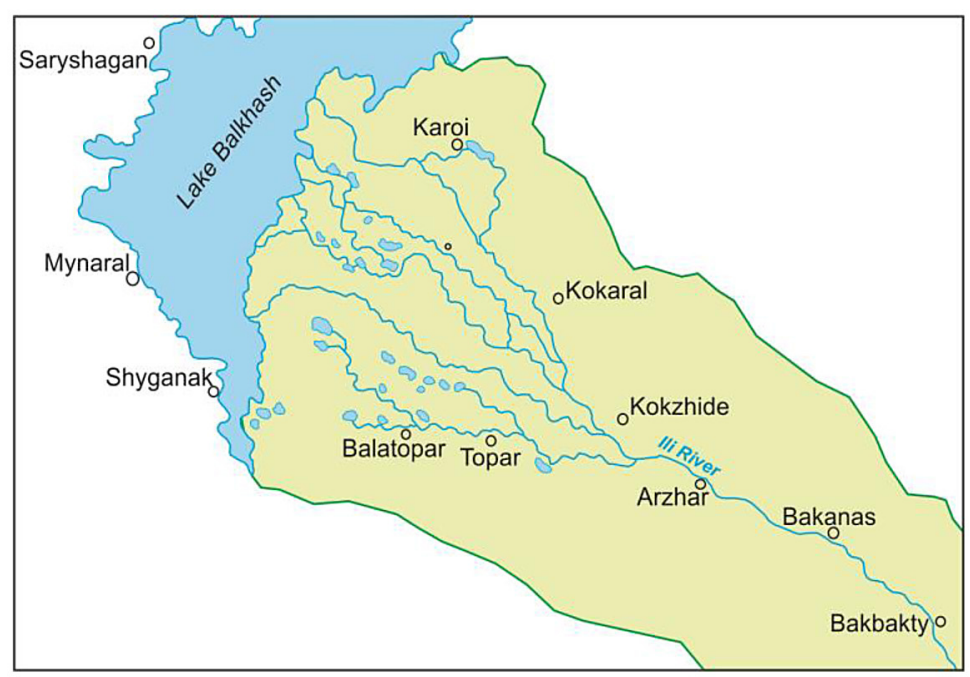

Fig. 1. The map-scheme of dela of Ile River

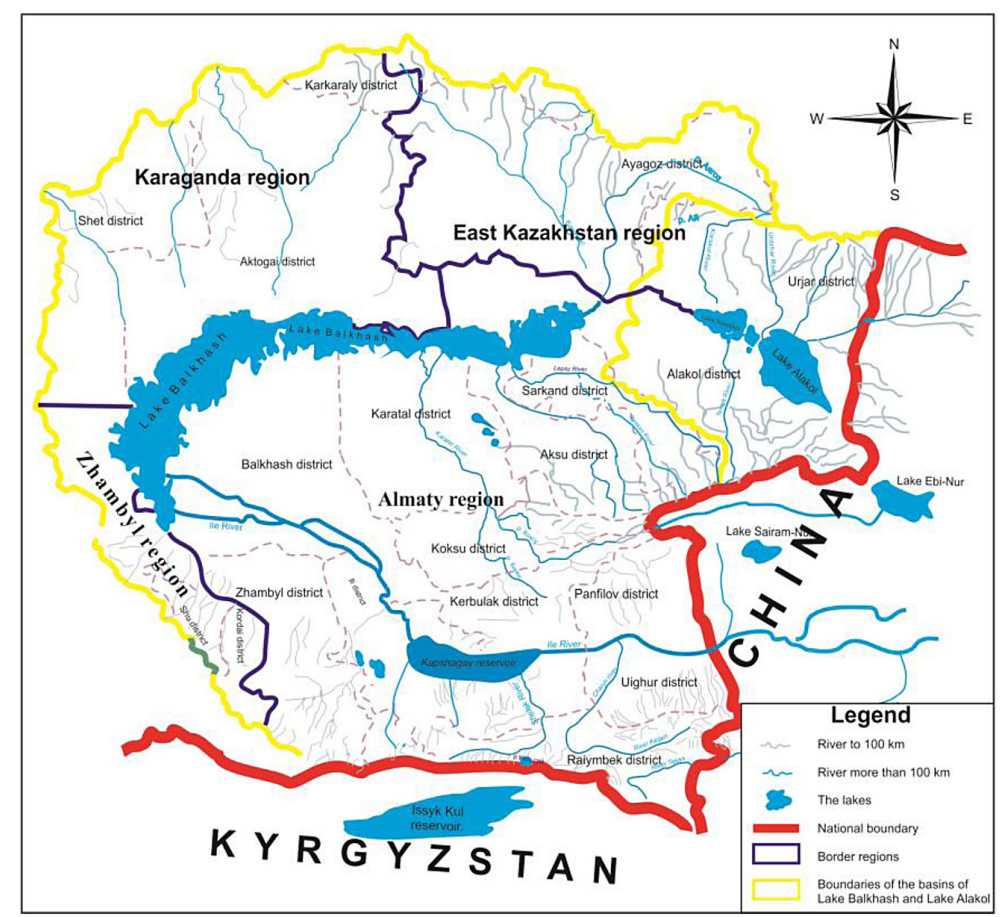

Fig. 2. Balkash-Alakol basin 
periods of year. The highest value of the suspended sediment load discharge is observed in these times of year. Currently, the amounts of suspended sediments load in the composition of liquid runoff of Ile River are $164 \mathrm{mg} / \mathrm{l}$ in autumn and $1300 \mathrm{mg} / 1$ in spring (Fig. 3).

For this study, the volume of sediment entering the reservoir at the gauging station located above the Kapshagai reservoir basin was determined (Table 1)

\section{METHODOLOGY}

\section{Granulometric composition and sediment regime}

The sediment regime largely determines not only the conveyance capacity of the delta watercourses but also the ecological conditions of both delta itself, and its water objects [11].

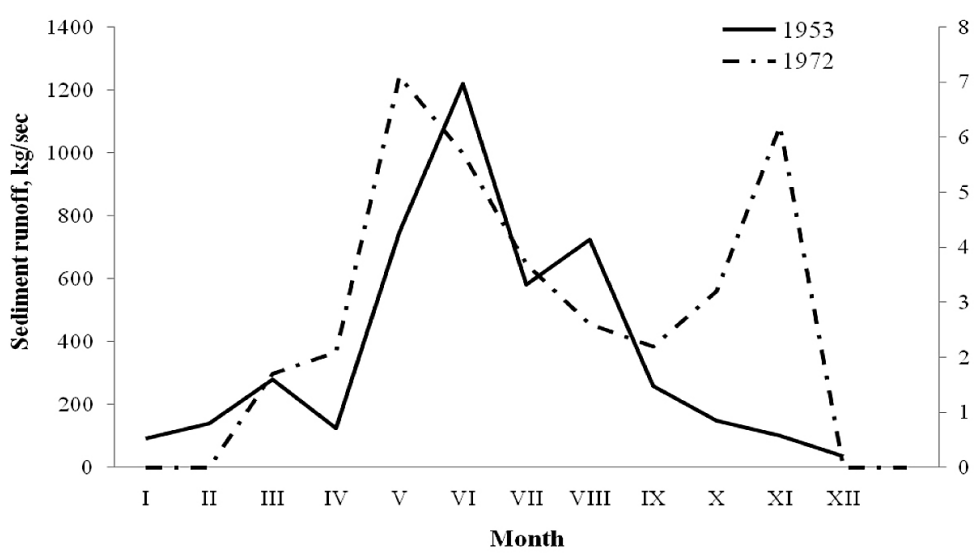

Fig. 3 Within-year distribution of average annual discharge of sediment load before and after the construction of the Kapshagai reservoir on the Ile River in the Kapshagai gauging station

Table 1. The value of the sediment runoff from the Ile River - gauging station $171 \mathrm{~km}$ above the Kapshagai reservoir

\begin{tabular}{|c|c|c|c|c|}
\hline Years & $\begin{array}{c}\text { Water discharge, } \\
\left(\mathrm{m}^{3} / \mathrm{sec}\right)\end{array}$ & $\begin{array}{c}\text { Sediment discharge, } \\
(\mathrm{kg} / \mathrm{sec})\end{array}$ & $\mathrm{W}_{\mathrm{R}}=31,5^{*} 10$ & W (volume, ton) \\
\hline 1981 & 484 & 310 & 9765000000 & 9765000 \\
\hline 1982 & 399 & 250 & 7875000000 & 7875000 \\
\hline 1983 & 390 & 190 & 5985000000 & 5985000 \\
\hline 1984 & 375 & 170 & 5355000000 & 5355000 \\
\hline 1985 & 452 & 350 & 11025000000 & 11025000 \\
\hline 1986 & 404 & 190 & 5985000000 & 5985000 \\
\hline 1987 & 525 & 360 & 11340000000 & 11340000 \\
\hline 1988 & 680 & 540 & 17010000000 & 17010000 \\
\hline 1989 & 421 & 230 & 7245000000 & 7245000 \\
\hline 1990 & 436 & 280 & 8820000000 & 8820000 \\
\hline 1991 & 444 & 270 & 8505000000 & 8505000 \\
\hline 1992 & 356 & 167 & 5260500000 & 5260500 \\
\hline 1993 & 500 & 339 & 10678500000 & 10678500 \\
\hline 1994 & 450 & 280 & 8820000000 & 8820000 \\
\hline 1995 & 317 & 125 & 3937500000 & 3937500 \\
\hline 1996 & 415 & 238 & 7497000000 & 7497000 \\
\hline 1997 & 388 & 207 & 6520500000 & 6520500 \\
\hline 1998 & 556 & 402 & 12663000000 & 12663000 \\
\hline 1999 & 573 & 423 & 13324500000 & 13324500 \\
\hline 2000 & 522 & 363 & 11434500000 & 11434500 \\
\hline & & & & \\
\hline
\end{tabular}


In this section, the impact of the Kapshagai reservoir creation on the change of the granulometric composition of suspended sediment and load was considered.

In order to analyze the granulometric composition of the sediment, the years of 1965 (before constructing of Kapshagai Hydropower Station) and 1982 year (after constructing of Kapshagai Hydropower Station) were taken into account. The data on the granulometric composition of suspended and bed sediment were used by the results of monitoring at the Ile River in the Kapshagai gauging station $[12,13]$.

The average diameter and factor inhomogeneity of sediment were considered as the main characteristics of the granulometric composition of sediment. Tables 2 and 3 contain the data on the granulometric composition of suspended and bed sediment at various phases of the hydrological regime of the Ile River in the Kapshagai gauging station. The factor of inhomogeneity of sediment $(\eta)$ was calculated by means of the following formula [14]:

$$
\eta=\frac{d_{60}}{d_{10}}
$$

where: $d_{60}$ and $d_{10}-$ diameters corresponding to $60 \%$ and $10 \%$ integral curve of granulometric composition.

The analysis of the content of the Tables 1 and 2 before the construction of the Kapshagai Hydropower Station shows that the size of particles of the suspended sediments $(0.005 / 0.5 \mathrm{~mm})$ varied in much wider range than the bed sediments $(0.01 / 0.5 \mathrm{~mm})$. Therewith, the factor of inhomogeneity suspended sediment was close to inhomogeneous $(\eta=5 / 6 \mathrm{~mm})$, whereas the factor of heterogeneity of bed sediment did not exceeding $\eta=1.5$, i.e. grounds were homogeneous [15].

The changes in the size and uniformity of the particles of bed sediment by water regime phases, before the construction of the Kapshagai Hydropower Station were not observed. However, for the suspended sediment at the rise of flood, it differs by increasing of homogeneity and increase in the size of the particle (Fig. 4).

Upon the construction of the Kapshagai Hydropower Station for suspended load, a significant increase (more than 10 times) in the size of particles sediment (Table 4) and equally substantial increase in homogeneity were observed. An increase in the heterogeneity of particles was noted

Table 2. The granulometric composition of the suspended sediment at various phases of the hydrological regime of the Ile River in the Kapshagai gauging station for 1965

\begin{tabular}{|c|c|c|c|c|c|c|c|c|c|c|}
\hline \multirow{2}{*}{ Diameter, mm } & \multicolumn{2}{|c|}{$12 / \mathrm{IV}$} & \multicolumn{2}{|c|}{$31 / \mathrm{V}$} & \multicolumn{2}{|c|}{$17 / \mathrm{VI}$} & \multicolumn{2}{|c|}{$20 / \mathrm{VII}$} & \multicolumn{2}{|c|}{ 08/VIII } \\
\hline & $\%$ & $d_{\text {ave }}$ & $\%$ & $\mathrm{~d}_{\mathrm{ave}}$ & $\%$ & $\mathrm{~d}_{\mathrm{ave}}$ & $\%$ & $d_{a v e}$ & $\%$ & $\mathrm{~d}_{\mathrm{ave}}$ \\
\hline 0,005 & 34,5 & 0,17 & 47,7 & 0,24 & 20,3 & 0,10 & 37,2 & 0,19 & 36 & 0,18 \\
\hline 0,01 & 31,9 & 0,32 & 27,6 & 0,28 & 40,4 & 0,40 & 46,8 & 0,47 & 41,7 & 0,42 \\
\hline 0,05 & 17,8 & 0,89 & 18,9 & 0,95 & 25,0 & 1,25 & 12,7 & 0,64 & 10,2 & 0,51 \\
\hline 0,1 & 8,00 & 0,80 & 5,20 & 0,52 & 8,00 & 0,80 & 1,60 & 0,16 & 7,3 & 0,73 \\
\hline 0,2 & 4,30 & 0,86 & 0,30 & 0,06 & 5,60 & 1,12 & 1,50 & 0,30 & 4,2 & 0,84 \\
\hline 0,5 & 3,50 & 1,75 & 0,30 & 0,15 & 0,70 & 0,35 & 0,20 & 0,10 & 0,6 & 0,30 \\
\hline$d_{\text {aver }}$ & \multicolumn{2}{|c|}{0,05} & \multicolumn{2}{|c|}{0,02} & \multicolumn{2}{|c|}{0,04} & \multicolumn{2}{|c|}{0,02} & \multicolumn{2}{|c|}{0,03} \\
\hline$\eta$ & \multicolumn{2}{|c|}{6,00} & \multicolumn{2}{|c|}{ 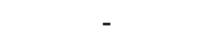 } & \multicolumn{2}{|c|}{2,85} & \multicolumn{2}{|c|}{5,00} & \multicolumn{2}{|c|}{5,30} \\
\hline
\end{tabular}

Table 3. The granulometric composition of the bed sediment at various phases of the hydrological regime of the Ile River in the Kapshagai gauging station for 1965

\begin{tabular}{|c|c|c|c|c|c|c|c|c|c|c|}
\hline \multirow{2}{*}{ Diameter, mm } & \multicolumn{2}{|c|}{$25 / I I$} & \multicolumn{2}{|c|}{$29 / I I I$} & \multicolumn{2}{|c|}{$17 / \mathrm{VI}$} & \multicolumn{2}{|c|}{ 08/VIII } & \multicolumn{2}{|c|}{$11 / X I$} \\
\hline & $\%$ & $\mathrm{~d}_{\mathrm{ave}}$ & $\%$ & $\mathrm{~d}_{\mathrm{ave}}$ & $\%$ & $\mathrm{~d}_{\mathrm{ave}}$ & $\%$ & $d_{\text {ave }}$ & $\%$ & $d_{\text {ave }}$ \\
\hline 0,01 & 18,2 & 0,002 & 7,9 & 0,001 & 7,3 & 0,001 & 15,2 & 0,002 & 19,1 & 0,001 \\
\hline 0,05 & 39,1 & 0,020 & 35,9 & 0,018 & 50,7 & 0,025 & 24,7 & 0,012 & 41,9 & 0,021 \\
\hline 0,1 & 21,8 & 0,022 & 21,9 & 0,022 & 19,0 & 0,019 & 18,6 & 0,019 & 13,4 & 0,013 \\
\hline 0,2 & 13,6 & 0,027 & 18,7 & 0,037 & 14,0 & 0,028 & 19,2 & 0,038 & 7,00 & 0,014 \\
\hline 0,5 & 7,30 & 0,037 & 15,6 & 0,078 & 9,0 & 0,045 & 22,3 & 0,112 & 18,6 & 0,093 \\
\hline$d_{\text {aver }}$ & \multicolumn{2}{|c|}{0,001} & \multicolumn{2}{|c|}{0,002} & \multicolumn{2}{|c|}{0,001} & \multicolumn{2}{|c|}{0,002} & \multicolumn{2}{|c|}{0,001} \\
\hline$\eta$ & \multicolumn{2}{|c|}{1,46} & \multicolumn{2}{|c|}{1.54} & \multicolumn{2}{|c|}{1,30} & \multicolumn{2}{|c|}{1,82} & \multicolumn{2}{|c|}{1,39} \\
\hline
\end{tabular}


by phases of the hydrological regime during the rise of flood (Fig. 5).

As for bed sediments (Table 5) after constructing of Kapshagai Hydropower Station, a manyfold increase in the particles size (more than 1000 times) and decrease of its homogeneity (almost two times) were noted. Simultaneously, significant changes either in the particles size or homogeneity of the bed load were not observed by the phases of the hydrological regime. The changes in the granulometric composition of suspended and bed sediment of Ile River identified above were caused by the following reasons.

\section{Evaluation of the amount of suspended sediment load settling in the bowl of the Kapshagai reservoir}

The distribution of the sediment load to the arms of the Ile river delta was determined for the periods before and after the Kapshagai reservoir construction. At the gauging station located below the Kapshagai reservoir, a reduction of the considered hydrological characteristics was observed. At the Ile River in the Ushzharma gauging station, the water discharge decreased from $472 \mathrm{~m}^{3} / \mathrm{sec}$ to $382 \mathrm{~m}^{3} / \mathrm{sec}$ and the reduction of the discharge of sediment was from $442 \mathrm{~kg} / \mathrm{sec}$ to $81.3 \mathrm{~kg} / \mathrm{sec}$. This means that the liquid runoff decreased for $1.24 \%$, sediment runoff for $18.4 \%$. These indicators are presented in Table 6.

According to the data presented in Table 6, a sharp decrease and reduction in the value of sediment runoff is observed in the periods after the construction of the Kapshagai reservoir. The main reason for this is that sediments are transported through the reservoir which is stretched for the considerable distance in the plan and has a maximum depth of $70 \mathrm{~m}$. Therefore, in the first place, it is very important to know how much sediment is settling on the bottom of the basin of the reservoir.

Using the data from Table 6, the volume of sediment value deposited on the Kapshagai reservoir basin was determined (Table 7). Total quantitative volume of the settled sediment in the

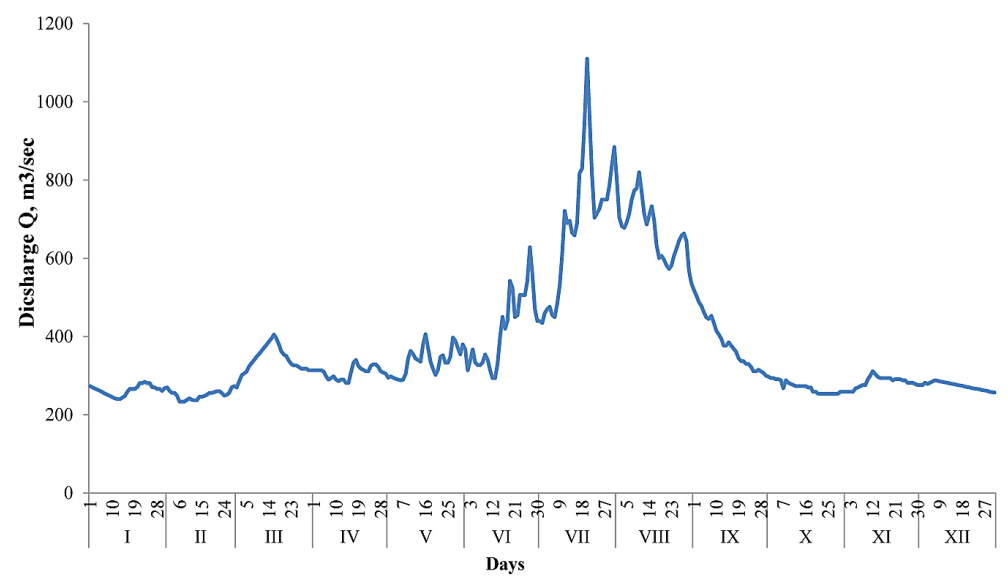

Fig. 4. Hydrograph of water discharge before construction of the Kapshagai Hydropower Station for 1965

Table 4. Granulometric composition of the suspended sediment at various phases of the hydrological regime of the Ile River in the Kapshagai gauging station for 1982

\begin{tabular}{|c|c|c|c|c|c|c|}
\hline \multirow{2}{*}{ Diameter, mm } & \multicolumn{2}{|c|}{$30 / \mathrm{IV}$} & \multicolumn{2}{|c|}{$31 / \mathrm{VI}$} & \multicolumn{2}{|c|}{$30 / \mathrm{VII}$} \\
\hline & $\%$ & $\mathrm{~d}_{\mathrm{ave}}$ & $\%$ & $\mathrm{~d}_{\mathrm{ave}}$ & $\%$ & $d_{\text {ave }}$ \\
\hline 0,001 & 25,2 & 0,03 & 14,7 & 0,01 & 2,30 & 0,002 \\
\hline 0,005 & 12,6 & 0,06 & 7,40 & 0,04 & 6,90 & 0,035 \\
\hline 0,01 & 18,9 & 0,19 & 14,7 & 0,15 & 19,7 & 0,197 \\
\hline 0,05 & 3,20 & 0,16 & 35,6 & 1,78 & 59,8 & 2,990 \\
\hline 0,1 & 32,4 & 3,24 & 16,9 & 1,69 & 6,30 & 0,630 \\
\hline 0,2 & 6,90 & 1,38 & 9,30 & 1,86 & 1,20 & 0,240 \\
\hline 0,5 & 0,80 & 0,40 & 1,4 & 0,70 & 3,80 & 1,900 \\
\hline $\mathrm{d}_{\mathrm{aver}}$ & \multicolumn{2}{|c|}{0,055} & \multicolumn{2}{|c|}{0,062} & \multicolumn{2}{|c|}{0,060} \\
\hline$\eta$ & \multicolumn{2}{|c|}{ - } & \multicolumn{2}{|c|}{-} & \multicolumn{2}{|c|}{1,71} \\
\hline
\end{tabular}




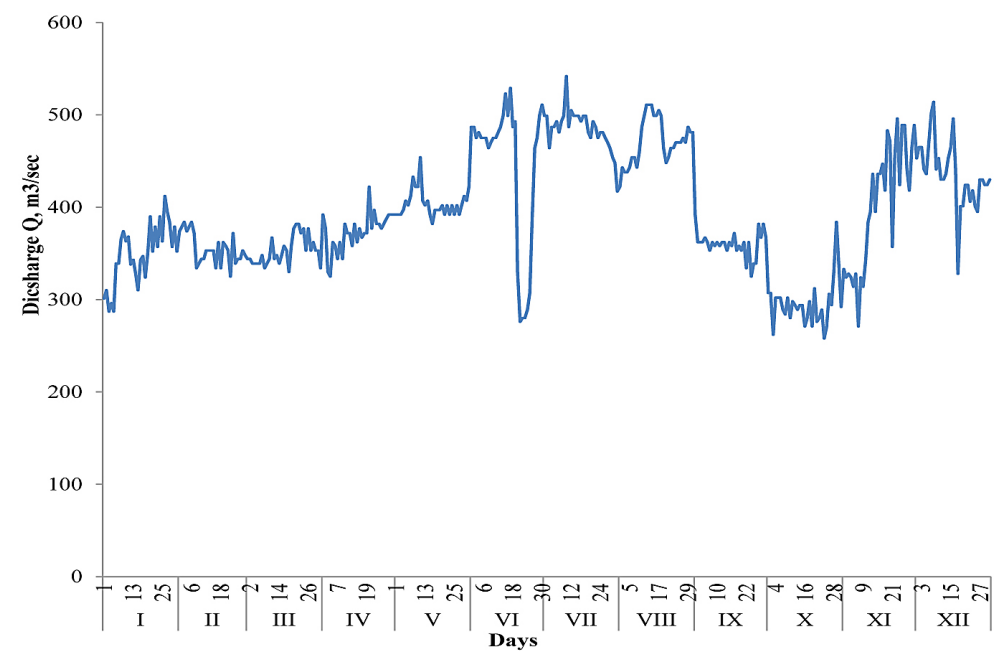

Fig. 5. Hydrograph of water discharge after the construction of the Kapshagai Hydropower Station for 1982

Table 5. The granulometric composition of bed sediment at various phases of the hydrological regime of the Ile River in the Kapshagai gauging station for 1982

\begin{tabular}{|c|c|c|c|c|c|c|c|c|}
\hline \multirow{2}{*}{ Diameter, mm } & \multicolumn{2}{|c|}{$31 / 1$} & \multicolumn{2}{|c|}{$28 / I I$} & \multicolumn{2}{|c|}{$23 / I I I$} & \multicolumn{2}{|c|}{$30 / I V$} \\
\hline & $\%$ & $d_{\text {ave }}$ & $\%$ & $\mathrm{~d}_{\mathrm{ave}}$ & $\%$ & $d_{\text {ave }}$ & $\%$ & $d_{\text {ave }}$ \\
\hline 0,01 & 0,40 & 0,00 & 1,40 & 0,01 & 0,20 & 0,002 & 0,1 & 0,001 \\
\hline 0,05 & 1,30 & 0,07 & 5,80 & 0,29 & 0,60 & 0,03 & 0,2 & 0,01 \\
\hline 0,1 & 3,50 & 0,35 & 3,10 & 0,31 & 0,80 & 0,08 & 0,6 & 0,06 \\
\hline 0,2 & 8,20 & 1,64 & 4,40 & 0,88 & 11,9 & 2,38 & 5,3 & 1,06 \\
\hline 0,5 & 4,60 & 2,30 & 2,40 & 1,20 & 5,40 & 2,70 & 4,0 & 2,00 \\
\hline 1 & 3,00 & 3,00 & 1,60 & 1,60 & 3,40 & 3,40 & 3,0 & 3,00 \\
\hline 2 & 3,80 & 7,60 & 3,60 & 7,20 & 5,60 & 11,2 & 5,0 & 10,0 \\
\hline 5 & 6,70 & 33,5 & 6,20 & 31,0 & 4,60 & 23,0 & 6,8 & 34,0 \\
\hline 10 & 7,00 & 70,0 & 5,00 & 50,0 & 10,0 & 100 & 7,5 & 75,0 \\
\hline 20 & 18,0 & 360 & 13,0 & 260 & 13,0 & 260 & 7,5 & 150 \\
\hline 50 & 26,0 & 1300 & 38,5 & 1925 & 32,5 & 1625 & 37,5 & 1875 \\
\hline 100 & 17,5 & 1750 & 15,0 & 1500 & 12,0 & 1200 & 22,5 & 2250 \\
\hline$d_{\text {aver }}$ & \multicolumn{2}{|c|}{35,3} & \multicolumn{2}{|c|}{37,8} & \multicolumn{2}{|c|}{32,3} & \multicolumn{2}{|c|}{44,0} \\
\hline$\eta$ & \multicolumn{2}{|c|}{2,06} & \multicolumn{2}{|c|}{2,48} & \multicolumn{2}{|c|}{2,08} & \multicolumn{2}{|c|}{1,75} \\
\hline
\end{tabular}

Kapshagai reservoir basin can reach an average of 5 to 15 million tons per year.

As a result of the creation of the Kapshagai reservoir, practically all suspended and bed sediments of the Ile River are deposited in the bowl of the reservoir. In the tail-water of the Kapshagai Hydropower Station the treated water of the Ile River flows, which considerably increases its transporting capacity. This, in its turn, contributes to involving into transfer of the suspended sediments of larger particles downstream of the Ile River [16].

The increase in the homogeneity of the particles during this period is caused by the increase of the flow velocity in the river channel and, respectively, by the increase in its transporting capacity. A significant increase in the heterogeneity of the bed sediment is also explained by the increase of the transport capacity of flow, wash away small particles and the form the bed material on the bed of the river $[7,9,16]$.

\section{RESULT AND DISCUSSION}

The analysis of the content of the Tables 2 and 3 shows that before the construction of the Kapshagai Hydropower Station, the size of particles of the suspended sediments $(0.005 \div 0.5 \mathrm{~mm})$ varied in much wider range than the bed sediments $(0.01-0.5 \mathrm{~mm})$. Therewith, the factor of inhomogeneity of the suspended sediment was close to inhomogeneous $(5-6 \mathrm{~mm})$, whereas the factor of 
Table 6. The main characteristics of the liquid runoff and sediment runoff of the Ile River, before and after the construction of the Kapshagai reservoir

\begin{tabular}{|c|c|c|c|c|c|c|c|c|}
\hline \multirow{3}{*}{ Inflows } & \multicolumn{4}{|c|}{ Before construction } & \multicolumn{4}{|c|}{ After construction } \\
\hline & \multicolumn{2}{|c|}{$\begin{array}{l}\text { Water discharge, } \\
\left(\mathrm{m}^{3} / \mathrm{sec}\right)\end{array}$} & \multicolumn{2}{|c|}{$\begin{array}{c}\text { Sediment discharge, } \\
(\mathrm{kg} / \mathrm{sec})\end{array}$} & \multicolumn{2}{|c|}{$\begin{array}{l}\text { Water discharge, } \\
\left(\mathrm{m}^{3} / \mathrm{sec}\right)\end{array}$} & \multicolumn{2}{|c|}{$\begin{array}{c}\text { Sediment discharge } \\
(\mathrm{kg} / \mathrm{sec})\end{array}$} \\
\hline & $\mathrm{Q}, \mathrm{m}^{3} / \mathrm{sec}$ & $\mathrm{Cv}$ & $\mathrm{R}, \mathrm{kg} / \mathrm{sec}$ & $\mathrm{Cv}$ & $\mathrm{Q}, \mathrm{m}^{3} / \mathrm{sec}$ & $\mathrm{Cv}$ & $\mathrm{R}, \mathrm{kg} / \mathrm{sec}$ & $\mathrm{Cv}$ \\
\hline $\begin{array}{l}\text { Ile River in gauging } \\
\text { station Kapshagai }\end{array}$ & 482 & 0,23 & 392 & 0,48 & 419 & 0,21 & 3,4 & 0,98 \\
\hline $\begin{array}{l}\text { lle River in gauging } \\
\text { station Ushzharma }\end{array}$ & 472 & 0,14 & 442 & 0,34 & 382 & 0,16 & 81,3 & 0,48 \\
\hline
\end{tabular}

Table 7. The volume of the sediment deposited on the basin of the Kapshagai reservoir

\begin{tabular}{|c|c|c|c|c|c|c|}
\hline Years & $\begin{array}{c}\text { Water discharge, } \\
\mathrm{m}^{3} / \mathrm{sec}\end{array}$ & $\begin{array}{c}\text { Sediment } \\
\text { discharge, } \\
\mathrm{kg} / \mathrm{sec}\end{array}$ & $\mathrm{W}_{\mathrm{R}}=31,5^{*} 10$ & $\begin{array}{c}\mathrm{W} \text { (volume, } \\
\text { ton) }\end{array}$ & $\Delta \mathrm{W}_{\mathrm{R}}$ & $\Delta \mathrm{W}_{\mathrm{R}} \%$ \\
\hline 1981 & 437 & 0,9 & 28350000 & 28350 & 9736650000 & 99,7 \\
\hline 1982 & 392 & 2,0 & 63000000 & 63000 & 7812000000 & 99,2 \\
\hline 1983 & 322 & 2,0 & 63000000 & 63000 & 5922000000 & 98,9 \\
\hline 1984 & 337 & 2,6 & 81900000 & 81900 & 5273100000 & 98,5 \\
\hline 1985 & 344 & 3,4 & 107100000 & 107100 & 10917900000 & 99,0 \\
\hline
\end{tabular}

heterogeneity of bed sediment did not exceed 1.5, i.e. grounds were homogeneous.

The spring warming leads to the melting of snows, and this, in turn, exposes the basin area to intense erosion. The increase in the water discharge promotes enhancing the channel bed erosion. In the summer period the same process is repeated, and because of the wash out of the bed, sedimentation of bottom of the reservoir's basin replenished by suspended load.

The main feature of the within-year distribution of the suspended sediment load is its sharp variability during the year. For instance, for the observed period, the average discharge of the suspended sediment load in the inflow of the Ile River, Iir duct in January is $4.6 \mathrm{~kg} / \mathrm{s}$, and in April it was $100 \mathrm{~kg} / \mathrm{s}$, i.e. it increased by 20 times. The within-year distribution of the sediment runoff by the inflows of the delta is also highly variable. Because of the sediment accumulation in the bowl of the reservoir, the characteristics of solid runoff in the downstream of the river decreased several times. According to the observations on the Ile River in the Kapshagai gauging station, the water discharge decreased from $482 \mathrm{~m}^{3} / \mathrm{s}$ to $419 \mathrm{~m}^{3} / \mathrm{s}$, and at the same time, the sediment runoff reduced from $392 \mathrm{~kg} / \mathrm{s}$ to $3.4 \mathrm{~kg} / \mathrm{s}$. It means that the liquid runoff decreased by $1.15 \%$, and the sediment runoff by approximately $100 \%$.
As a result, it was revealed that the withinyear distribution of the sediment load on the arms of the river delta is sharply uneven (Fig. 6).

A sharp increase in the sediment runoff is observed in the spring months. The average monthly discharge of the suspended sediment in February is less than observable in March. A decrease in the discharge of the suspended sediment load in the following gauging stations: the Ile River in the Ushzharma gauging station - 3 times; in the inflow of the Ile River, Iir duct - a gauging station $2.5 \mathrm{~km}$ from delta -6 times observed; in the gauging station in the Zhideli inflow $-16 \mathrm{~km}$ from the source - it decreased 10 times. Additionally, in the Ile River, in the Suminka inflow located $6 \mathrm{~km}$ from the source and in Zhideli inflow $-1 \mathrm{~km}$ below the branch, a decrease of 40 times was observed [12].

While studying the sediment mode and their within-year distribution, it was revealed that the main factor determining the variability of these characteristics is the Kapshagai reservoir. As for the periods before the construction of the Kapshagai reservoir between water runoff and sediment runoff, there is a good link; in order to restore a number of sediment runoff, a link between the sediment runoff and the water runoff was used (Fig. 6). The calculations results indicated that $99 \%$ of the incoming sediments settle in the reservoir basin can be formulated. 


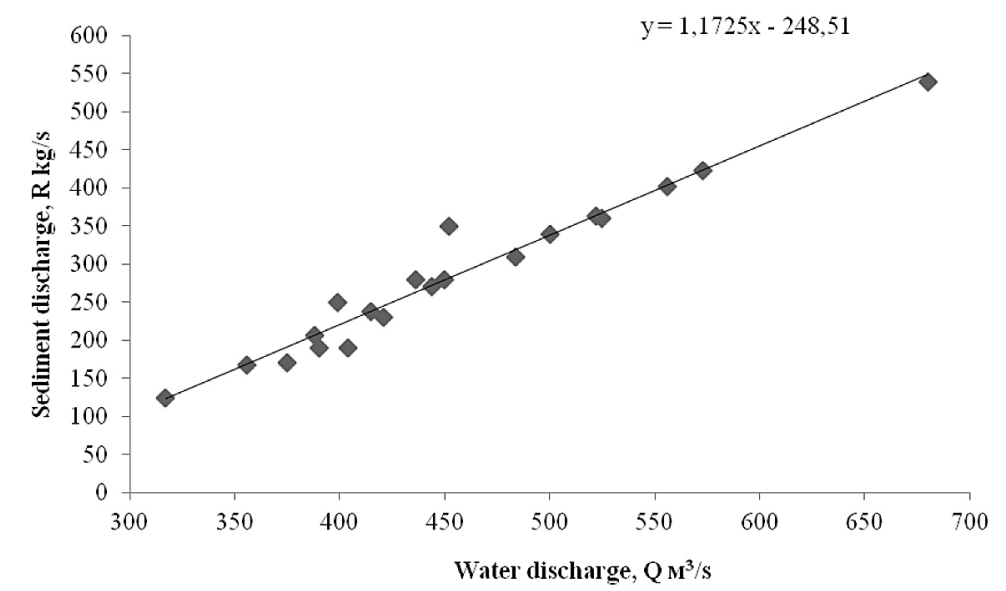

Fig. 6. Link between the water runoff and sediment runoff of the Ile River - gauging station $171 \mathrm{~km}$ above the Kapshagai reservoir

\section{CONCLUSIONS}

The construction of the Kapshagai reservoir led to a significant decrease of the sediment runoff and caused a considerable impact to the granulometric composition of the suspended sediment load downstream the Ile River. Downstream the reservoir, the sizes of sediment particle are increasing; simultaneously, a decrease for the suspended sediment is observed. Furthermore, for the bed sediments, an increase of heterogeneity of granulometric composition was measured.

As shown in this paper, there are from 5 to 15 million tons of sediment settled in the Kapshagai reservoir, with an average of 10 million tons per year. This is $99 \%$ of the total volume of the sediment flowing to the basin of the reservoir.

The obtained regularities in the changes of the granulometric composition of the suspended and bed sediment loads after the construction of the Kapshagai reservoir, which were shown in this study, must be considered at planning and realization of hydroeconomic and nature conservation activities downstream and on the delta of the Ile River.

\section{REFERENCES}

1. Tursunov A., S. Romanova, A. Myrzakhmetov Analysis of the Current Situation and Tendencies of Further Development of Worldwide and Local Science "Safety of Water", International Journal of Engineering and Innovative Technology, 3(2), 2013, 263-266.

2. Nysanbayev E.N., A.R. Medeu, and A.A. Tursunova, Water resources of Central Asia: challenges and threats, problems of use [in Russia]. Water resources of Central Asia and their use, Proceedings of the international scientific-practical conference, "Water for Life", Book 1. Almaty: Institute of Geography, LLP, 2016, 4-8.

3. Medeu A.R. (Ed.). National Atlas of the Republic of Kazakhstan. Vol. 1: Natural conditions and resources, 2nd ed. revised and amended, Almaty: LLP Institute of Geography, 2010, $150 \mathrm{p}$.

4. Dostay Zh.D., R.I. Galperin, S.K. Davletgaliev, and S.A. Alimkulov. Natural waters of Kazakhstan: resources, regime, quality and forecast [in Russia]. Questions of Geography and Geoecology, 2012, 4, $18-24$.

5. Klei, A.J. Dietz, U. Gessner, A. Galayeva, A. Myrzakhmetov, C. Kuenzer Evaluation of seasonal water body extents in Central Asia over the past 27 years derived from medium-resolution remote sensing data" International Journal of Applied Earth Observation and Geoformation, 26, 2014, 335-349

6. Samakova A.B. (2003) The problems of hydro-ecological sustainability in the Balkhash Lake. "Kaganat", Almaty, p. 3-171.

7. Dostay Zh. Upravlenie gidroecosistemoi ozera Balkhash. Institute of Geography, Almaty, 2009, p 235

8. Alimkulov S., A. Tursunova, A. Saparova, K. Kulebaev, A. Zagidullina, A. Myrzahmetov Resources of River Runoff of Kazakhstan. International Journal of Engineering and Advanced Technology, 8(6), 2019, 2242-2250

9. Dostay Z., S. Alimkulov, A. Tursunova, A. Myrzakhmetov Modern hydrological status estuary of Ili River. Arab J Geosci, DOI 10.1007/s12517-012-0561-2, Published online: 11 April 2012.

10. A. Tursunov Ot Arala do Labnora. Almaty, Khanagat, 2002, p. 384. 
11. Problems of conservation ecosystems of inland waters in Central Asia and Southern Caucasus. Central Asia Regional Ecological Center, Almaty, 2005, p. 171.

12. State Water Cadastre Long-term data on regime and resources of land surface water resources 1976-1980. Gidrometeoizdat, Vol. 1, Leningrad, 1981, p. 587.

13. The hydrological yearbooks Balkhash lake basin and Central Kazakhstan rivers basin. Gidrometeoizdat, Leningrad, 5(5-8), 1982, p. 337.
14. Chingrihets L., K. Duskayev Sediment load calculation. Kazakh University, Almaty, 2007, p. 216.

15. Karaushev A. Theory and methods applied in estimation of river drifts. Gidrometeoizdat, Leningrad, 1977, p. 272.

16. Duskayev K., Z. Zhanabaeva, A. Myrzakhmetov Particularities of controlling Ili River water discharge regime and Kapshagai waterstorage reservoir transporting capacity. Kazakh National University reference: Geography series, Kazakh University, Vol. 2, 2010, 97-102. 